\title{
KAJIAN KONSTITUSI INDONESIA DARI AWAL KEMERDEKAAN SAMPAI \\ REFORMASI KONSTITUSI PASCA ORDE BARU
}

\author{
Oleh : Kus Eddy Sartono
}

\begin{abstract}
Abstrak
Sejarah konstitusi Indonesia dapat dikatakan telah melewati berbagai tahap perkembangan. Tiap tahap memunculkan model ketatanegaraan yang khas, sampai karena trauma masa lalu terutama akibat praktek politik Orde Baru yang menyalah gunakan konstitusi untuk tujuan kekuasaannya yang sentralistik dan otoriter, memunculkan ide untuk mengamandemen UUD 1945.

Tahap perkembangan konstitusi di Indonesia dapat dikelompokkan menjadi beberapa periode. Periode pertama berlaku UUD 1945, periode kedua berlaku Konstitusi RIS 1949, periode ketiga berlaku Undang-Undang Dasar Sementara 1950, Periode keempat berlaku kembali UUD 1945 beserta Penjelasannya. Setelah itu UUD 1945 diubah berturut-turut pada tahun 1999, 2000, 2001, 2002 dengan menggunakan naskah yang berlaku mulai 5 Juli 1959 sebagai standar dalam melakukan perubahan di luar teks yang kemudian dijadikan lampiran yang tak terpisahkan dari naskah UUD 1945.

Mengamandemen konstitusi (undang-undang dasar) jelas bukan urusan sederhana. Sebab undang-undang dasar merupakan desains utama negara untuk mengatur berbagai hal fundamental dan strategis, dari soal struktur kekuasaan dan hubungan antar kekuasaan organ negara sampai hak asasi manusia. Proses amandemen UUD 1945 terjadi secara bertahap selama empat kali. Ada berbagai kekurangan dalam empat tahap amandemen tersebut yang mendapat sorotan tajam diantara para pengamat, yang memunculkan ide perlunya dibentuk Komisi Konstitusi yang akan membantu melakukan koreksi dan mengatasi kekurangan-kekurangan itu untuk amandemen mendatang.
\end{abstract}

\section{A.PENDAHULUAN}

Hampir semua negara yang mengalami transisi ke demokrasi menjadikan reformasi konstitusi sebagai bagian tak terpisahkan dari pembaharuan politik mereka. Demikian pentingnya reformasi konstitusi itu, sehingga kehadirannya dipandang sebagai suatu keharusan. Tidak jelas benar kapan suatu negara yang tengah mengalami transisi mulai melaksanakan reformasi konstitusi. Sejauh yang dapat dibaca dari berbagai literatur mengenai transisi ke demokrasi, pengalaman masing-masing negara dalam hal ini relatif berbeda. Filipina misalnya mulai melakukan reformasi konstitusi dengan membentuk komisi konstitusi, dimana tugas utamanya adalah menuliskan kembali undang-undang 
dasar negeri itu tak lama setelah Presiden Marcos dijatuhkan, dan setelah pemerintahan baru Cory Aquino terbentuk ( Effendy Bahtiar, 2000: 339).

Idealnya, suatu konstitusi dibuat untuk memenuhi kebutuhan, yaitu terciptanya hubungan kekuasaan yang seimbang antara cabang-cabang kekuasaan yang ada. Akan tetapi karena suatu konstitusi itu merupakan produk zamannya,tidak jarang ia ditulis untuk mengakomodasi kepentingan-kepentingan waktu itu. Karenanya, sebenarnya tanpa adanya perubahan besar pun, reformasi konstitusi dapat dilakukan, baik melalui cara amandemen, perubahan dan penggantian konstitusi. Ini dilakukan ketika suatu konstitusi sudah tidak lagi mampu mengakomodasi kepentingan zamannya di atas mana proses penyelenggaraan negara hendak ditumpukan.

Tulisan ini hendak mengupas perkembangan konstitusi di Indonesia sejak awal kemerdekaan sampai terjadinya reformasi konstitusi pasca pemerintahan Orde Baru, serta kajian tentang hasil amandemen UUD 1945.

\section{B. KONSTITUSI NEGARA}

\section{Pengertian dan Konsep Dasar Konstitusi}

Istilah dalam bahasa Inggris "constitution" atau dalam bahasa Belanda "constitutie " secara harafiah sering diterjemahkan dalam bahasa Indonesia UndangUndang Dasar. Permasalahannya penggunaan istilah undang-undang dasar adalah bahwa kita langsung membayangkan sesuatu naskah tertulis. Padahal istilah constitution bagi banyak sarjana ilmu politik merupakan sesuatu yang lebih luas, yaitu keseluruhan peraturan - peraturan baik yang tertulis maupun yang tidak tertulis yang mengatur secara mengikat cara-cara bagimana suatu pemerintahan diselenggarakan dalam suatu masyarakat. Kebiasaan menerjemahkan istilah constitution menjadi undang-undang dasar, hal ini sesuai dengan kebiasaan orang Belanda dan Jerman, yang dalam percakapan sehari-hari memakai kata "Grondwet" (Grond = dasar; wet = undang-undang) dan grundgesetz (Grund = dasar ; gesetz = undang-undang )yang keduanya menunjukkan naskah tertulis (Miriam Budiardjo, 2007: 95). 
Pengertian konstitusi dalam praktek ketatanegaraan umumnya dapat mempunyai dua arti :

a)lebih luas daripada undang-undang dasar

b)sama dengan pengertian undang-undang dasar

Kata konstitusi dapat mempunyai arti lebih luas daripada pengertian undang-undang dasar, karena pengertian undang-undang dasar hanya meliputi naskah tertulis saja dan disamping itu masih terdapat konstitusi yang tidak tertulis, yang tidak tercakup dalam undang-undang dasar (Kaelan, 2004:180). Para penyusun Undang-Undang Dasar 1945 menganut arti konstitusi lebih luas daripada undang-undang dasar, sebab dalam Penjelasan Undang-Undang Dasar 1945 dikatakan :'Undang-Undang Dasar suatu Negara ialah hanya sebagian dari hukumnya dasar negara itu. Undang-Undang Dasar adalah hukum yang tertulis, sedang di sampingnya Undang-Undang Dasar berlaku juga Hukum Dasar yang tidak tertulis, ialah aturan-aturan dasar yang timbul dan terpelihara dalam praktek penyelenggaraan negara, meskipun tidak tertulis". Namun dalam masa Republik Indonesia Serikat 27 Desember 1949 - 17 Agustus 1950, penyusun Konstitusi RIS menerjemahkan secara sempit istilah konstitusi sama dengan undang-undang dasar. Hal ini terbukti dengan disebutnya istilah Konstitusi Republik Indonesia Serikat bagi Undang-Undang Dasar Republik Indonesia Serikat ( Totopandoyo, 1981: 25-26).

Menurut E.C.S Wade dalam bukunya "Constitutional Law" (Miriam Budiardjo, 2007, 96) undang-undang dasar adalah naskah yang memaparkan rangka dan tugastugas pokok dari badan-badan pemerintahan suatu negara dan menentukan pokok-pokok cara kerja badan-badan tersebut.

Ditinjau dari segi kekuasaan maka undang-undang dasar dapat dipandang sebagai lembaga atau kumpulan asas-asas yang menetapkan bagaimana kekuasaan itu dibagi antara beberapa lembaga kenegaraan. Mengacu konsep Trias politika kekuasaan dibagi antara badan eksekutif, legislatif dan yudikatif. Undang-undang dasar menentukan bagaimana pusat-pusat kekuasaan itu bekerjasama dan menyesuaikan diri satu sama lain; undang-undang dasar merekam hubungan-hubungan kekuasaan dalam suatu Negara.

Dalam negara yang menganut asas demokrasi konstitusional undang-undang dasar mempunyai fungsi yang khas yaitu membatasi kekuasaan pemerintahan sedemikian rupa sehingga penyelenggara kekuasaan tidak bersifat sewenang-wenang. Sehingga hak-hak 
warga negara diharapkan terlindungi . Pembatasan-pembatasan ini tercermin dalam undang-undang dasar. Jadi dalam anggapan ini undang-undang dasar mempunyai fungsi yang khusus dan merupakan perwujudan atau manifestasi dari hukum yang tertinggi yang harus ditaati, bukan hanya oleh rakyat, tetapi oleh pemerintah serta penguasa sekalipun.

Setiap undang-undang dasar memuat ketentuan-ketentuan mengenai soal-soal sebagai berikut:

1)Organisasi Negara, misalnya pembagian kekuasaan antara badan legislatif, eksekutif dan yudikatif; dalam Negara federal pembagian kekuasaan antara pemerintah federal dengan pemerintah Negara bagian; prosedur penyelesaian masalah pelanggaran yurisdiksi oleh salah satu badan pemerintah dan sebagainya.

2)Hak-hak asasi manusia.

3)Prosedur mengubah undang-undang dasar

4)Adakalanya memuat larangan untuk mengubah sifat tertentu dari undang-undang dasar. Hal ini untuk menghindari terulangnya kembali hal-hal yang baru saja diatasi. 5)Memuat cita-cita rakyat dan asas asas ideologi negara (Miriam Budiardjo, 2007: 101).

Undang-Undang Dasar 1945 mengandung semangat dan merupakan perwujudan dari pokok-pokok pikiran yang terkandung dalam Pembukaan Undang-Undang Dasar 1945, merupakan rangkaian kesatuan pasal-pasal yang bulat dan terpadu. Di dalamnya menurut Noor MS Bakry (1994: 120) berisi materi yang pada dasarnya dapat dibedakan antara empat hal, yaitu:

1)Pengaturan tentang fungsi sistem pemerintahan negara.

2)Ketentuan fungsi dan kedudukan lembaga negara

3)Hubungan antara negara dengan warga negaranya.

4)Ketentuan hal-hal lain sebagai pelengkap.

\section{2..Konstitusi-Konstitusi yang pernah digunakan di Indonesia}

Suatu undang-undang dasar jika tidak lagi mencerminkan konstelasi politik atau tidak memenuhi harapan aspirasi rakyat, dapat dibatalkan dan diganti dengan undangundang dasar baru. Misalnya, di Perancis sesudah dibebaskan dari pendudukan tentara Jerman, dianggap perlu mengadakan undang-undang dasar baru yang mencerminkan lahirnya Negara Perancis baru. Hal ini juga terjadi di Indonesia, Miriam Budiardjo 
(2007: 104) membagi empat tahap perkembangan undang-undang perkembangan undang-undang dasar sebagai berikut:

1)tahun1945 (Undang-Undang Dasar Republik Indonesia yang defacto hanya berlaku di Jawa, Madura, dan Sumatra).

2)tahun 1949 (Undang-Undang Dasar Republik Indonesia yang defacto berlaku seluruh Indonesia, kecuali Irian Barat).

3)tahun 1959 (Undang-Undang Dasar Republik Indonesia 1945 dengan demokrasi

Terpimpin, disusul Demokrasi Pancasila, Undang-Undang Dasar ini mulai 1963 berlaku di seluruh Indonesia termasuk Irian Barat)

Apabila ditinjau dari sudut perkembangan demokrasi sejarah Republik Indonesia Miriam Budiardjo (2007:105) membagi dalam tiga tahap, yaitu:

1) masa 1945-1959 sebagai Republik Indonesia ke-I (Demokrasi Parlementer) yang didasari tiga Undang-Undang Dasar berturut-turut, yaitu: 1945, 1949 dan 1950.

2) Masa 1959-1965 sebagai Republik ke-II (demokrasi Terpimpin) yang didasari Undang-Undang Dasar 1945.

3) Masa 1965 sampai sekarang sebagai Republik Indonesia ke-III (Demokrasi Pancasila yang didasari oleh Undang-Undang Dasar 1945.

Pemikiran ini disampaikan pada tahun 1970-an jauh hari sebelum jatuhnya rezim Suharto, sehingga jika kita tinjau saat ini dapat ditambahkan masa Republik ke-III periode antara tahun 1965-1998. Kemudian tahun 1998 sampai saat ini dapat ditambahkan masa Republik ke-IV dengan menggunakan Undang-Undang Dasar 1945 pasca amandemem (Demokrasi masa transisi).

Jimly Assidiqie (2007: 73) jika ditinjau dari sudut perkembangan naskah undangundang dasar, maka sejak proklamasi 17 Agustus 1945 sampai sekarang, tahap-tahap sejarah konstitusi Indonesia dapat dikatakan telah melewati enam tahap perkembangan, yaitu:

1) Periode tanggal 18 Agustus 1945 - 27 Desember 1949;

2) Periode tanggal 27 Desember 1949 - 17 Agustus 1950;

3) Periode tanggal 17 Agustus 1950 - 5 Juli 1959;

4) Periode tanggal 5 Juli 1959 - 19 Oktober 1999;

5) Periode tanggal 19 Oktober 1999 - 10 Agustus 2002; 
6) Periode tanggal 10 Agustus 2002 sampai dengan sekarang.

Pada periode pertama berlaku UUD 1945, periode kedua berlaku Konstitusi RIS 1949, periode ketiga berlaku Undang-Undang Dasar Sementara 1950, Periode keempat berlaku kembali UUD 1945 beserta Penjelasannya. Setelah itu UUD 1945 diubah berturut-turut pada tahun 1999, 2000, 2001, 2002 dengan menggunakan naskah yang berlaku mulai 5 Juli 1959 sebagai standar dalam melakukan perubahan di luar teks yang kemudian dijadikan lampiran yang tak terpisahkan dari naskah UUD 1945. Dengan demikian menurut Jimly Assidiqie (2007: 74) kurun waktu selama terjadi perubahan UUD 1945 dalam satu rangkaian kegiatan itu, dapat disebut sebagai satu kesatuan periode tersendiri , yaitu periode konstitusi transisional.

Bagaimana pelaksanaan ketatanegaraan berdasar undang-undang dasar pada setiap periodisasinya dapat diuraikan sebagai berikut:

1)Republik Pertama : UUD 1945

(18 Agustus 1945-27 Desember 1949)

Undang-Undang Dasar Republik Indonesia yang pertama adalah UUD 1945 yang disahkan pada tanggal 18 Agustus 1945, berlaku secara nasional sampai dengan tanggal 27 Desember 1949. Naskah Undang Undang Dasar Pertama tersebut disahkan oleh Panitia Persiapan Kemerdekaan Indonesia (PPKI). Penyusunan naskah Rancangan Undang-Undang Dasar 1945 dimulai dari pembentukan BPUPKI yang dilantik pada tanggal 28 Mei 1945. Pembentukan badan ini merupakan realisasi janji Pemerintah Jepang akan memberikan kemerdekaan kepada Indonesia kelak kemudian hari. BPUPKI mengadakan sidang-sidang yang dapat dikelompokkan menjadi dua masa persidangan; Sidang pertama mulai dari tanggal 29 Mei 1945-1 Juni 1945 dan masa persidangan kedua tanggal 10 Juli-17 Juli 1945. Dari persidangan-persidangan BPUPKI tersebut berhasil menyusun naskah komplit Rancangan Undang-Undang Dasar meliputi :
a)Pernyataan Indonesia merdeka.
b)Pembukaan Undang-Undang Dasar 
c)Undang-Undang Dasar teridiri atas pasal-pasal (Noor Ms Bakry, 1994: 23).

Dengan selesainya tugas BPUPKI, pemerintah Jepang membentuk Panitia Persiapan Kemerdekaan Indonesia (PPKI) yang bertugas untuk mempersiapkan segala sesuatu yang berhubungan dengan kemerdekaan Indonesia. Pada sidang tanggal 18 Agustus PPKI berhasil mengesahkan naskah Undang-Undang Dasar 1945 dari naskah Rancangan Undang-Undang Dasar hasil kerja BPUPKI tentunya dengan beberapa perubahan di sana sini. Terutama tentang dasar negara : Ketuhanan dengan kewajiban menjalankan syari'at Islam bagi pemeluk-pemeluknya sebagai mana termuat dalam Piagam Jakarta diubah menjadi Ketuhanan Yang Maha Esa.

Dari 18 Agustus 1945 sampai 27 Desember 1949 berlakulah Undang-Undang Dasar 1945. Menurut ketentuan undang-undang dasar ini sistem pemerintahan Indonesia bersifat presidensiil, dalam arti bahwa para menteri tidak bertanggungjawab kepada badan legislatif, tetapi hanya bertindak sebagai pembantu presiden. Akan tetapi mulai bulan November 1945, berdasarkan maklumat Wakil Presiden No. X tanggal 16 Oktober 1945, Pengumuman Badan Pekerja 11 November 1945, dan Maklumat Pemerintah tanggal 14 November 1945, tanggung jawab politik terletak ditangan para menteri. Keadaan ini merupakan awal dari suatu sistem pemerintahan parlementer yang praktis dipertahankan sampai tahun 1959 pada masa Undang-Undang Dasar 1945 dinyatakan berlaku kembali, melalui Dekrit Presiden. Jadi mulai 14 November 1945 sampai 27 Desember 1949 sistem pemerintahan yang diselenggarakan berlainan dengan sistem pemerintahan sebagaimana diatur dalam naskah Undang-Undang Dasar 1945 (Miriam Budiardjo, 2007: 115-116).

2) Republik Kedua : Konstitusi RIS (27 Desember 1945-17 Agustus 1950)

Dalam kondisi Indonesia yang baru saja menyatakan kemerdekaan, Belanda berkeinginan untuk berkuasa lagi di Indonesia, melalui Agresi I tahun 1947 dan Agresi II tahun 1948. Karena perlawanan sengit bangsa Indonesia, Belanda gagal menguasai Indonesia. Tahun1949 diadakan Konferensi Meja Bundar (KMB) di Den Haag, Belanda. Salah satu hasil KMB yaitu mendirikan Negara Republik Indonesia Serikat. Rancangan naskah Konstitusi Republik Indonesia Serikat juga diputuskan dalam KMB dan disepakati mulai berlaku pada tanggal 27 Desember 1949. 
Dengan berdirinya Negara Republik Indonesia Serikat (RIS), Negara Republik Indonesia (RI) secara hukum masih tetap ada. Negara RI berubah status menjadi salah satu negara bagian dari Negara RIS. Undang-Undang Dasar 1945 yang semula berlaku untuk seluruh wilayah Indonesia mulai tanggal 27 Desember 1949 hanya berlaku dalam wilayah Negara Bagian Republik Indonesia saja.

Negara RIS dengan Konstitusi RIS nya berlangsung sangat pendek sekali karena memang tidak sesuai dengan jiwa proklamasi kemerdekaan yang menghendaki negara kesatuan, tidak menginginkan negara dalam negara, sehingga beberapa negara bagian meleburkan diri lagi dengan Republik Indonesia. Semangat kebersamaan ini nampak dengan adanya Penetapan Presiden RIS tentang penggabungan negara-negara bagian ke Republik Indonesia, yaitu:

a)Tanggal 9 Maret Negara bagian dan daerah Jawa Timur, Jawa Tengah, Madura, Subang, dan Padang masuk ke dalam Republik Indonesia.

b)Tanggal 11 Maret 1950, memasukkan Negara Pasundan menjadi daerah Republik Indonesia.

c)Tanggal 24 Maret 1950, memasukkan Kalimantan Timur dan Sumatera Selatan menjadi daerah Republik Indonesia.

d)Tanggal 4 April 1950, Bangka, Belitung, Riau, Banjar, Dayak Besar, Kota

Waringin, Kalimantan Tenggara masuk dalam daerah Republik Indonesia.

Sehingga hanya Negara bagian Indonesia Timur dan Negara bagian Sumatera Timur saja yang belum masuk ke dalam Republik Indonesia yang berpusat di Yogyakarta. Pada tanggal 19 Mei 1950 disusunlah Piagam Persetujuan antara Pemerintah RIS yang sekaligus mewakili Negara bagian Indonesia Timur menyatakan menyetujui membentuk Negara kesatuan. Dan tindak lanjut dari Piagam Persetujuan tersebut terbentuklah Negara Kesatuan dengan berdasar Undang-Undang Dasar Sementara 1950 tanggal 17 Agustus 1950 (Noor Ms Bakry, 2001: 34).

3)Republik Indonesia Ketiga; UUDS 1950

(17 Agustus 1950-5 Juli 1959)

Perubahan ketatanegaraan dari Negara serikat menjadi Negara kesatuan yang berdasar Undang-Undang Dasar Sementara 1950 yang didalam Pembukaannya memuat 
dasar negara Pancasila, akan tetapi pelaksanaan sistem pemerintahannya menggunakan sistem kabinet parlementer yang tidak cocok dengan jiwa Pancasila, sehingga kabinetnya jatuh bangun, yang rata-rata umur tiap-tiap kabinet kurang dari satu tahun. Noor Ms Bakry (2001:36) memaparkan dari tahun 1950 sampai tahun 1959 telah terjadi pergantian kabinet sebanyak 7 kali, ialah :
a)Kabinet Natsir (6 September 1950 sampai dengan 27 April 1951)
b)Kabinet Sukiman (27 April 1951 sampai dengan 3 April 1952)
c)Kabinet Wilopo (3 April 1952 sampai dengan 1 Agustus 1953)
d)Kabinet Alisastroamidjojo I (1 Agustus 1953 sampai dengan 12 Agustus 1955)
e)Kabinet Burhannudin Harahap (12 Agustus 1955 sampai dengan 24 Maret 1956)
f)Kabinet Alisastroamidjojo II (24 Maret 1956 sampai dengan 9 April 1957)
g)Kabinet Djuanda (9 April 1957 sampai dengan 10 Juli 1959).

Dalam periode pemerintahan tahun 1950 sampai dengan tahun 1959 terjadi tujuh kali pergantian kabinet, maka dapat dipastikan stabilitas nasional sangat terganggu.

Seperti halnya dengan Konstitusi RIS tahun 1949, Undang Undang Dasar Negara Kesatuan Republik Indonesia tahun1950 juga bersifat sementara. Sifat kesementaraan ini disebutkan dalam Pasal 134, dimana diharuskan Konstituante bersama-sama dengan Pemerintah menyusun Undang-Undang Dasar Republik Indonesia yang akan menggantikan Undang-Undang Dasar yang berlaku saat itu, yaitu UUDS 1950.Berbeda dengan di masa berlakunya Konstitusi RIS tahun 1949 yang tidak sempat merealisasikan pembentukan konstituante atau lembaga pembentuk undang-undang dasar, di bawah UUDS 1950 sebagai realisasi dari Pasal 134, Pemilihan umum berhasil dilaksanakan.

Pemilihan umum pertama di Indonesia diadakan pada tanggal 29 September 1955 untuk memilih anggota Dewan Perwakilan Rakyat, dan tanggal 15 Desember 1955 untuk memilih wakil-wakil rakyat yang duduk di dalam Dewan Konstituante yang akan membentuk Undang-Undang Dasar baru sebagai pengganti Undang-Undang Dasar Sementara 1950. Konstituante sebagi Dewan Penyusun Undang-Undang dasar dalam sidangnya sejak tahun 1956 sampai tahun 1959 belum berhasil membuat undang-undang dasar baru, selalu mengalami kesulitan kerena tidak pernah tercapai kesepakatan. Pihakpihak yang berbeda pendapat tidak pernah mencapai suara dari jumlah anggota 
Konstituante. Keadaan ini jika diteruskan akan menemui jalan buntu yang membahayakan kelangsungan hidup bangsa dan Negara. Untuk itu Presiden Soekarno mencari jalan keluarnya dengan mengeluarkan Dekrit Presiden 5 Juli 1959, yang berisikan, yaitu:

1) Menetapkan pembubaran Konstituante

2) Menetapkan UUD 1945 berlaku lagi terhitung mulai tanggal penetapan Dekrit, dan tidak berlakunya lagi UUDS 1950.

3) Menetapkan dalam waktu sesingkat-singkatnya pembentukan MPRS dan DPAS.

Dekrit ini mendapat dukungan sebagian besar rakyat Indonesia, yang lebih penting lagi melalui Dekrit ini terjadi perubahan ketatanegaraan Indonesia, naskah Undang-Undang Dasar 1945 menjadi berlaku kembali sebagai hukum tetinggi dalam Negara Kesatuan Republik Indonesia.

4)Republik Indonesia Keempat: UUD 1945 Orde Lama (1959-1965)

Ciri-ciri periode ini ialah dominasi yang sangat kuat dari presiden, terbatasnya peranan partai politik, berkembangnya pengaruh komunis dan meluasnya peranan ABRI sebagai unsur sosial politik. Undang-Undang Dasar 1945 memberi kesempatan bagi seorang presiden untuk bertahan selama sekurang-kurangnya lima tahun. Akan tetapi Ketetapan MPRS No. III/MPRS/1963 yang mengangkat Soekarno sebagai presiden seumur hidup telah membatalkan pembatasan waktu lima tahun ini. Tahun 1960 Presiden Soekarno membubarkan Dewan Perwakilan Rakyat hasil pemilihan umum, padahal dalam penjelasan Undang-Undang Dasar 1945 secara eksplisit ditentukan bahwa presiden tidak mempunyai wewenang untuk berbuat demikian. Dewan Perwakilan Rakyat Gotong Royong yang menggantikan Dewan Perwakilan Rakyat hasil pemilihan umum ditonjolkan peranannya sebagai pembantu Presiden sedangkan fungsi kontrolnya ditiadakan. Bahkan Pimpinan Dewan Perwakilan Rakyat dijadikan menteri sehingga fungsi mereka lebih sebagai pembantu presiden dari pada wakil rakyat. Kuatnya posisi presiden juga merambah dalam bidang-bidang lain diluar bidang eksekutif. Berdasarkan 
Undang-Undang No. 19 tahun 1964 Presiden diberi wewenang untuk campur tangan di bidang yudikatif. Dan masih Banyak lagi penyimpangan-penyimapangan terhadap Undang-Undang Dasar 1945 sebagaimana dibeberkan oleh Miriam Budiardjo (2007: 71). Puncaknya pecahnya peristiwa G 30 S/PKI telah mengakhiri periode demokrasi terpimpin dan membuka jalan untuk di mulainya masa demokrasi Pancasila.

\section{5)Republik Kelima : UUD 1945 Orde Baru}

(1966-1998)

Pergeseran kekuasaan dari Soekarno ke Suharto menimbulkan perubahan Orde dari Orde lama ke Orde Baru. Implementasi Undang-Undang Dasar 1945 mengalami beberapa koreksi. Orde Baru mempunyai tekad untuk melakukan koreksi atas berbagai penyimpangan terhadap Undang-Undang Dasar 1945 pada masa Orde Lama. Pada mulanya Orde baru berupaya untuk memperbaiki nasib bangsa dalam berbagai bidang kehidupan. Dan rakyat merasakan peningkatan kondisi di berbagai bidang kehidupan melalui serangkaian program yang dituangkan dalam GBHN dan Repelita. Namun dalam perjalanannya Orde Baru berubah wajah menjadi kekuasaan yang otoriter. Penafsiran pasal-pasal UUD 1945 dimanipulasi untuk kepentingan mempertahankan kekuasaan. Bahkan Undang_Undang Dasar 1945 yang singkat dan fleksibel mudah disalah tafsirkan dan menguntungkan penguasa, disakralkan untuk tidak diamandemen bukan demi kebaikan rakyat, tetapi demi kekuasaan itu sendiri. Pengalaman pada masa Orde Lama dengan Undang-Undang Dasar 1945 posisi presiden yang sangat kuat, terulang lagi pada masa Orde Baru. Posisi legislatif berada di bawah presiden. Hak asasi rakyat juga dibatasi. Kekuasaan tanpa kontrol akibatnya pemerintahan Orde Baru cenderung melakukan penyimpangan di berbagai aspek kehidupan. Korupsi Kolusi dan Nepotisme (KKN) merajalela. Terjadi ketidakmerataan hasil pembangunan, kesenjangan kaya dan miskin semakin melebar, utang semakin membengkak, akhirnya menumpuk menjadi krisis multi dimensi. Dipelopori mahasiswa rakyat menuntut reformasi di segala bidang. Akhirnya Rezim Orde Baru tumbang dengan mundurnya Soeharto tanggal 21 Mei 1998. 
6)Republik Keenam : UUD 1945 Diamandemen

(1998-sekarang)

Pengalaman sejarah pada masa lalu baik masa Orde Lama maupun masa Orde Baru, bahwa penerapan terhadap pasal-pasal Undang-Undang Dasar 1945 yang memiliki sifat "multi interpretable" atau dengan kata lain berwayuh arti, sehingga mengakibatkan terjadinya sentralisasi kekuasaan di tangan presiden. Hal inilah yang melatarbelakangi perlunya dilakukan amandemen terhadap Undang-Undang Dasar 1945. Amandemen merupakan keharusan karena hal itu akan mengantar bangsa Indonesia kearah tahapan baru penataan terhadap ketatanegaraan (Kaelan, 2004: 177).

Amandemen terhadap Undang-Undang Dasar 1945 dilakukan oleh bangsa Indonesia sejak tahun 1999, dimana amandemen yang pertama dilakukan dengan memberikan tambahan dan perubahan terhadap 9 pasal Undang-Undang Dasar 1945. Kemudian amandemen kedua dilakukan pada tahun 2000, amandemen ketiga dilakukan tahun 2001 dan amandemen terakhir dilakukan tahun 2002 dan disahkan pada tanggal 10 Agustus 2002. Oleh karena itu naskah resmi Undang-Undang Dasar Negara Republik Indonesia tahun 1945 menurut Jimly Assiddiqie (2007: 98) terdiri atas lima naskah, yaitu:

1) Naskah Undang-Undang Dasar 1945 seperti yang diberlakukan oleh Dekrit Presiden 5 Juli 1959

2) Naskah Perubahan Pertama UUD 1945 yang disahkan pada tahun 1999;

3) Naskah Perubahan Kedua UUD 1945 yang disahkan pada tahun 2000;

4) Naskah Perubahan Ketiga UUD 1945 yang disahkan pada tahun 2001;

5) Naskah Perubahan Keempat UUD 1945 yang disahkan pada tahun 2002.

\section{KAJIAN HASIL AMANDEMEN UUD 1945}

Meskipun tuntutan amandemen terhadap UUD 1945 semakin menguat akan tetapi MPR sebagai lembaga yang memiliki kewenangan untuk melakukan amandemen terhadap UUD 1945 tidak gegabah dalam melaksanakannya demi menjaga kelangsungan hidup Negara Kesatuan Republik Indonesia. Dalam melakukan amandemen ada kesepakatan bersama anggota MPR yang dituangkan dalam kesepakatan dasar anggota 
Panitia Ad Hoc Badan Pekerja MPR dalam menyusun rancangan naskah perubahan UUD 1945, yaitu bahwa :

1) Tidak mengubah Pembukaan UUD 1945

2) Tetap mempertahankan Negara Kesatuan Republik Indonesia

3) Mempertegas Sistem Pemerintahan Presidensial

4) Penjelasan UUD 1945 ditiadakan serta hal-hal normatif dalam Penjelasan dimasukkan dalam pasal-pasal

5) Perubahan dilakukan dengan cara adendum ( Sekretariat Jenderal MPR-RI, 2003: 25).

Proses amandemen UUD 1945 terjadi secara bertahap selama empat kali yaitu : tahun 1999, tahun 2000, tahun 2001 dan tahun 2002. Amandemen pertama disahkan tanggal 19 Agustus 1999, berisi : sembilan pasal . Ketentuan yang diubah dalam kesembilan pasal tersebut berkenaan dengan 16 butir ketentuan. Amandemen kedua UUD 1945 yang disahkan pada tanggal 18 Agustus 2000 dengan 59 butir ketentuan yang diatur dalam 25 pasal. Amandemen ketiga UUD 1945 disahkan pada tanggal 9 November 2001 menyangkut 23 pasal yang berkaitan 68 butir ketentuan. Dan amandemen keempat UUD 1945 disahkan pada tanggal 10 Agustus 2002 menyangkut 18 pasal berkenaan 31 butir ketentuan (Jimly Assidiqie, 2007: 101).

Keseluruhan amandemen Undang-Undang Dasar 1945 pada dasarnya meliputi :

1) Ketentuan mengenai hak-hak asasi manusia, hak dan kewajiban warga negara, serta mekanisme hubungannya dengan Negara dan prosedur untuk mempertahankannya apabila hak-hak itu dilanggar;

2) Prinsip-prinsip dasar tentang demokrasi dan rule of law serta mekanisme perwujudannya dan pelaksanaannya, seperti melalui pemilihan umum, dan lain-lain;

3) Format kelembagaan Negara dan mekanisme hubungan antar organ Negara serta sistem pertanggungjawaban para pejabatnya.

Dengan perkataan lain, menurut Jimly Assidiqie (2007:115) apa yang diatur dalam amandemen pertama sampai dengan amandemen keempat Undang-Undang Dasar 1945 
mencakup semua hal yang menjadi pokok materi semua undang-undang dasar negara modern di dunia.

Dengan amandemen UUD 1945, Lembaga MPR mengalami transformasi kedudukan dari lembaga tertinggi negara menjadi lembaga permusyawaratan rakyat yang lebih lemah kedudukannya. MPR menjadi salah satu organ negara yang menjalankan tugas-tugas konstitusional yang kedudukannya sederajat dengan lembaga-lembaga tinggi negara lainnya. MPR secara sukarela mengurangi kekuasaannya sendiri berdasarkan Undang-Undang Dasar, Presiden dan Wakil Presiden yang semula dipilih oleh MPR diubah menjadi dipilih langsung oleh rakyat. MPR mengurangi lagi kewenangannya sendiri dengan menegaskan status hukum dan materi ketetapan MPR/S yang pernah ditetapkan, dan sekaligus mengakhiri kewenangannya sendiri untuk menetapkan ketetapan MPR yang bersifat mengatur di masa-masa selanjutnya. Sehingga setelah amandemen MPR hanya memiliki kekuasaan melakukan perubahan Undang-Undang Dasar, melantik Presdien dan Wakil Presiden, serta memberhentikan Presiden/Wakil Presiden seusai masa jabatannya atau jikalau melanggar konstitusi. Oleh karena itu Presiden bersifat "Neben" bukan Untergeornet" dengan MPR karena Presiden dipilih langsung oleh rakyat. Susunan keanggotaan MPR mengalami perubahan dari semula terdiri atas anggota DPR ditambah dengan Utusan Daerah dan Utusan Golongan, menjadi anggota DPR ditambah dengan DPD. Pengurangan wewenang MPR merupakan konsekuensi logis dari perubahan pasal 1 ayat (2) UUD 1945 :"Kedaulatan ditangan rakyat dan dilakukan menurut Undang-Undang Dasar”. Berdasarkan ketentuan tersebut dapat disimpulkan bahwa dalam Negara Republik Indonesia pemegang kekuasaan tertinggi atau kedaulatan adalah ditangan rakyat dan realisasinya diatur dalam UndangUndang Dasar Negara. Sebelum dilakukan amandemen kekuasaan tertinggi dilakukan oleh Majelis Permusyawaratan Rakyat.

Pembagian kekuasaan menurut sebagaimana diatur dalam UUD 1945 adalah sebagai berikut:

1) Kekuasaan Eksekutif didelegasikan kepada Presiden (Pasal 4 ayat (1) UUD 1945).

2) Kekuasaan Legislatif didelegasikan kepada Presiden, DPR dan DPD (Pasal 5 ayat (1), pasal 19 dan pasal 22C UUD 1945). 
3) Kekuasaan Yudikatif didelegasikan kepada Mahkamah Agung (pasal 24 ayat (1) UUD 1945).

4) Kekuasaan Inspektif atau pengawasan didelegasikan kepada Badan Pemeriksa Keuangan (BPK) dan Dewan Perwakilan Rakyat (DPR). Hal ini termuat dalam UUD 1945 pasal 20 A ayat (1)”... DPR juga memiliki fungsi pengawasan”. Artinya DPR melakukan pengawasan terhadap Presiden selaku eksekutif.

5) UUD 1945 hasil amandemen tidak ada kekuasaan Konsultatif, yang sebelum diamandemen didelegasikan kepada Dewan pertimbangan Agung. Hal ini karena berdasarkan kenyataan pelaksanaan kekuasaan konsultatif tidak jelas fungsinya.

Menurut Kaelan (2004:184) mekanisme pendelegasian yang demikian ini dalam khasanah Ilmu Hukum Tatanegara dan Ilmu Politik dikenal dengan istilah "distribution of power" yang merupakan salah satu unsur mutlak dari negara demokrasi.

Dalam kaitan dengan kekuasaan kehakiman ada dua lembaga baru setelah amandemen UUD 1945 yaitu Komisi Yudisial suatu komisi yang bersifat mandiri yang berwenang mengusulkan pengangkatan hakim agung dan mempunyai wewenang lain dalam rangka menjaga dan menegakan kehormatan, keluhuran martabat serta perilaku hakim. Keanggotaan Komisi Yudisial diangkat dan diberhentikan oleh Presiden dengan persetujuan DPR. Di samping itu ada Mahkamah Konstitusi yang berwenang mengadili pada tingkat pertama dan terakhir yang putusannya bersifat final, untuk menguji undangundang terhadap Undang-Undang Dasar, memutus pembubaran partai politik, dan memutus perselisihan hasil pemilihan umum. Dibentuknya Mahkamah Konstitusi merupakan langkah maju dalam lembaga peradilan di Indonesia (Kaelan, 2004: 205).

Kekurang cermatan para perumus amandemen UUD 1945 adalah mengenai Pasal 28 yang berbunyi:"Kemerdekaan berserikat dan berkumpul, mengeluarkan pikiran dengan lisan dan tulisan dan sebagainya ditetapkan dengan undang-undang”. Menurut latarbelakang perumusannya pada tahun 1945 dulu, pasal ini dimaksudkan untuk melindungi hak asasi manusia, tetapi dengan modofikasi sedemikian rupa sehingga tidak langsung selesai dengan pemuatannya dalam UUD 1945. Menurut Jimly Assidiqie (2007: 135) jaminan hak asasi manusia dimaksud masih digantungkan kepada pengaturannya lebih lanjut dengan undang-undang. Dengan amandemen UUD 1945, substansi ketentuan pasal 28 dimuat secara tegas dalam pasal 28 E ayat (3) yang 
berbunyi: "Setiap orang berhak atas kebebasan berserikat, berkumpul dan mengeluarkan pendapat". Sehingga seharusnya rumusan Pasal 28 tersebut dicoret karena telah digantikan oleh Pasal 28E ayat (3).

Kekurangan yang lain adalah mengenai susunan dan sistematika UUD 1945 setelah diamandemen menjadi rancu dan tidak proporsional (Jimly Assidiqie, 2007: 134). Bab III berjudul Majelis Permusyawaratan Rakyat, sedangkan tentang Dewan Perwakilan Rakyat diatur dalam Bab VII, dan untuk Dewan Perwakilan Daerah sebagai lembaga baru diciptakan bab baru yaitu Bab VIIA. Padahal antara DPR, DPD dan MPR itu sama-sama merupakan lembaga negara dalam ranah kekuasaan legislatif. Sementara itu, Bab IV yang sebelumnya berjudul Dewan Pertimbangan Agung, dihapus sama sekali dari naskah UUD 1945, sehingga susunan UUD 1945 meloncat dari Bab III tentang Kekuasaan Pemerintahan Negara langsung ke Bab V tentang Kementerian Negara.

Adanya kekurangan dalam amandemen UUD 1945 adalah merupakan hal yang manusiawi karena banyaknya materi yang diubah, dikurangi, atau ditambah dengan amandemen pertama sampai keempat. Bertolak dari kekurangan inilah, memunculkan ide perlunya dibentuk Komisi Konstitusi yang akan membantu melakukan koreksi dan mengatasi kekuarangan-kekurangan itu untuk amandemen mendatang.

\section{PENUTUP}

Sejarah konstitusi Indonesia dapat dikatakan telah melewati berbagai tahap perkembangan. Tiap tahap memunculkan model ketatanegaraan yang khas, sampai karena trauma masa lalu terutama akibat praktek politik Orde Baru yang menyalah gunakan konstitusi untuk tujuan kekuasaannya yang sentralistik dan otoriter, memunculkan ide untuk mengamandemen UUD 1945.

Mengamandemen konstitusi (undang-undang dasar) jelas bukan urusan sederhana. Sebab undang-undang dasar merupakan desains untama negara untuk mengatur berbagai hal fundamental dan strategis, dari soal struktur kekuasaan dan hubungan antar kekuasaan organ negara sampai hak asasi manusia. Sistem ketatanegaraan dalam UUD akan menentukan nasib bangsa dan negara. Proses amandemen UUD 1945 terjadi secara bertahap selama empat kali yaitu tahun 1999, tahun 2000, tahun 2001 dan tahun 2002. 
Ada berbagai kekurangan dalam empat tahap amandemen tersebut yang mendapat sorotan tajam diantara para pengamat.

Adanya kekurangan dalam amandemen UUD 1945 adalah merupakan hal yang manusiawi karena banyaknya materi yang diubah, dikurangi, atau ditambah dengan amandemen pertama sampai keempat. Bertolak dari kekurangan inilah, memunculkan ide perlunya dibentuk Komisi Konstitusi yang akan membantu melakukan koreksi dan mengatasi kekurangan-kekurangan itu untuk amandemen mendatang.

\section{DAFTAR PUSTAKA}

Bakry Noor MS. 1994. Pancasila Yuridis Kenegaraan. Yogyakarta. Penerbit Liberty

Effendi Bahtiar. 2000. Reformasi Konstitusi Sebagai Prasyarat Demokratisasi

Pengalaman Indonesia. Analisis CSIS Tahun XXIX/2000, No. 4. Jimly Assiddiqie. 2007. Pokok-Pokok Hukum Tata Negara Indonesia. Jakarta PT Bhuana Ilmu Populer Kelompok Gramedia.

Kaelan, 2004. Pendidikan Pancasila. Yogyakarta. Penerbit Paradigma

Miriam Budiardjo. 2007. Dasar-Dasar Ilmu Politik. Jakarta. Penerbit Gramedia Pustaka Utama.

Sekretariat Jenderal MPR RI. 2003. Panduan dalam memasyarakatkan UUD 1945; Latar Belakang, Proses dan Hasil Perubahan UUD 1945. Jakarta.

Toto S.Pandoyo. 1981. Ulasan Terhadap Beberapa Ketentuan Undang-Undang Dasar 1945. Yogyakarta. Penerbit Liberty. 